\title{
Rhinolekos, a new genus with three new species of Hypoptopomatinae (Siluriformes: Loricariidae) from upper rio Paraná
}

\author{
Fernanda de Oliveira Martins and Francisco Langeani
}

Rhinolekos, new genus, and three new species, R. britskii, R. garavelloi, and $R$. schaeferi, are described from rio Paranaíba, upper rio Paraná drainage, central Brazil. Rhinolekos can be diagnosed by the following combination of characters: anterior portion of the compound supraneural-first dorsal-fin proximal radial contacting the neural spine of the $9^{\text {th }}$ or $10^{\text {th }}$ vertebrae; presence of the lateronasal plate; absence of the median rostral plate; presence of the pectoral-fin axillary slit just in juvenile specimens; ventral surface of pectoral girdle exposed only laterally; arrector fossae partially enclosed, with opening relatively large, extending laterally halfway towards pectoral-fin base; paired anterior process of the compound supraneural-first dorsalfin proximal radial bone absent; median plate series continuous to the caudal-fin origin; iris operculum present; pteroticsupracleithrum quadrangular in shape and not extending posteriorly; supraoccipital not contributing to the dorsal portion of the swimbladder capsule; subopercular plate present; dorsal and ventral margins of snout bearing odontodes roughly equivalent in size and shape to those on remainder of the head; caudal peduncle roughly rounded in cross section; longitudinal crests in supraoccipital absent; fourth infraorbital expanded ventrally.

Rhinolekos, gênero novo, e três espécies novas, $R$. britskii, $R$. garavelloi e $R$. schaeferi, são descritas do rio Paranaíba, drenagem do alto rio Paraná, região central do Brasil. Rhinolekos pode ser diagnosticado pela seguinte combinação de caracteres: porção anterior do composto supraneural-primeiro proximal radial da nadadeira dorsal contatando o espinho neural da nona ou décima vértebra; presença da placa látero-nasal; ausência da placa rostral mediana; presença da fenda peitoral axilar apenas nos juvenis; superfície ventral da cintura peitoral exposta apenas lateralmente; arrector fossae parcialmente fechado, abertura relativamente grande, estendendo-se em direção à base da nadadeira peitoral; processo anterior pareado do composto supraneural-primeiro proximal radial da nadadeira dorsal ausente; série mediana de placas contínua até a origem da nadadeira caudal; opérculo da íris presente; pterótico-supracleitro quadrangular, não se estendendo posteriormente; ausência de cristas no supraoccipital, este não contribuindo com a formação da porção dorsal da cápsula da bexiga natatória; placa subopercular presente; margens dorsal e ventral do focinho portando odontódes de tamanho e forma equivalentes aos demais da cabeça; pedúnculo caudal aproximadamente circular em corte transversal; quarto infraorbital expandido ventralmente.

Key words: Cascudinhos, Neotropical region, rio Paranaíba, Systematics, Taxonomy.

\section{Introduction}

The Hypoptopomatinae is considered a monophyletic group of the Loricariidae, including more than 80 species arranged in 19 genera (Reis \& Carvalho, 2007; Carvalho et al., 2008). Most hypoptopomatines are small-sized fishes, ranging from 20 to $35 \mathrm{~mm}$ in standard length, and are usually found in close association with marginal vegetation (Schaefer, 2003). In the last fifteen years, seven new genera and many new species were described for this subfamily, indicating the great diversity of this group that still remains fairly known.
During samplings in headwater streams of the rio Paranaíba, upper rio Paraná drainage, specimens of two new species of hypoptopomatines were captured. Additionally, examination of material from rio Paranaíba deposited in the fish collection of Museu de Ciências e Tecnologia da Pontifícia Universidade Católica do Rio Grande do Sul (MCP) prompted the discovery of another related new species. After comparisons, these species were not diagnosable within any previously described Hypoptopomatinae genus or species, therefore a new genus is proposed and three new species are described.

UNESP - Universidade Estadual Paulista, Instituto de Biociências, Letras e Ciência Exatas, Departamento de Zoologia e Botânica, Laboratório de Ictiologia. Rua Cristóvão Colombo, 2265, 15054-000 São José do Rio Preto, SP, Brazil. fernanda_martins2@hotmail.com 


\section{Material and Methods}

Measurements were made with digital calipers, point-topoint on the left side of the specimens, to the nearest $0.1 \mathrm{~mm}$, following Boeseman (1968) with modifications of Armbruster \& Page (1996), Schaefer \& Provenzano (1993), and Ribeiro et al. (2005). Head length was measured from the tip of the snout to the posterior tip of the supraoccipital. Plate counts followed Schaefer (1997) and nomenclature followed Bailey \& Baskin (1976) and Schaefer (1997). Plates and teeth were counted from both sides in cleared and stained (c\&s) specimens, prepared according to Taylor \& van Dyke (1985). Vertebrae counts included five from Weberian apparatus, and the compound caudal centrum was counted as a single element. Dorsal-fin rays counts include spinelet as the first unbranched ray.

Museum abbreviations for specimens examined are listed in Fricke \& Eschmeyer (2010) with the addition of LBP (Laboratório de Biologia de Peixes, UNESP, Botucatu, Brazil), cited therein erroneously as LPB.

\section{Results}

\section{Rhinolekos, new genus}

Type species. Rhinolekos britskii, new species.

Diagnosis. Rhinolekos differs from all other Hypoptopomatinae (sensu Schaefer, 1998) (except Microlepidogaster Eigenmann \& Eigenmann) by having the anterior portion of the compound supraneural-first dorsalfin proximal radial contacting the neural spine of the $9^{\text {th }}$ or $10^{\text {th }}$ vertebrae (Fig. 1) (vs. $8^{\text {th }}$ in Epactionotus Reis \& Schaefer and $7^{\text {th }}$ in all other hypoptopomatines). Also, Rhinolekos can be readily distinguished from the remaining Hypoptopomatinae (except Gymnotocinclus anosteos Carvalho, Lehmann \& Reis and Acestridium Haseman) by the presence of the lateronasal plate, a large plate between the second infraorbital plate and the nasal opening, anteriorly projected, surrounding the nostril (Fig. 2). Rhinolekos differs from Gymnotocinclus anosteos by having: dermal plates covering most of the body ( $v s$. extreme reduction of body dermal plates); lateral connecting bone fused to the lateral body plates ( $v s$. absence of lateral connecting bone); bifid hemal spines on caudal vertebrae posterior to first anal-fin proximal radial present ( $v s$. bifid hemal spines absent); all lateral body dermal plates with odontodes posteriorly curved, including the last ones on the caudal peduncle ( $v s$. odontodes on last dermal plates dorsally or anteriorly curved); maxillary barbel reduced, free from lower lip (vs. adnate to lower lip). Furthermore, Rhinolekos differs from Acestridium by having: preopercle emergent to skin surface and visible externally ( $v s$. preopercle not emergent and not visible externally in all
Hypoptopomatini taxa, including Acestridium); head and body relatively wide, not depressed ( $v s$. head and body very slender, depressed); anterior margin of snout markedly rounded, without projection ( $v s$. snout with a conspicuous spatulate projection); dorsal-fin insertion slightly posterior to pelvic-fin base (vs. dorsal fin placed well posterior to pelvic fin and just anterior to anal-fin origin).

Rhinolekos is similar to Microlepidogaster and Pseudotocinclus Nichols, concerning general body shape and may be phylogenetically related with these genera. However, Rhinolekos differs from Microlepidogaster by having ventral surface of pectoral girdle exposed only laterally (vs. totally exposed); arrector fossae partially enclosed, with opening relatively large, extending laterally halfway towards pectoral-fin base ( $v s$. opening reduced). Additionally, Rhinolekos differs from M. perforatus by the absence of the median rostral plate ( $v s$. presence); by presenting the pectoral-fin axillary slit only in juvenile specimens ( $v s$. pectoral-fin axillary slit present, even in adult specimens); paired anterior process of the compound supraneural-first dorsal-fin proximal radial bone absent (vs. present, linking the supraneural with the supraoccipital via ligament); median plate series continuous to the caudal-fin origin ( $v s$. median plate series truncated, ending before the caudal-fin base), and iris operculum present ( $v s$. absent). Finally, Rhinolekos differs from Pseudotocinclus by having the caudal peduncle roughly rounded in cross section ( $v s$. caudal peduncle distinctly square in cross section); longitudinal crests in supraoccipital absent ( $v s$. present); fourth infraorbital expanded ventrally ( $v s$. not expanded).

Distribution. Rhinolekos is restricted to streams of the rio Paranaíba drainage, Goiás State, central Brazil (Fig. 3).

Etymology. The generic name is a combination of the greek, rhinos $=$ nose, nostril and lekos $=$ plate, in reference to presence of the lateronasal plate. Gender masculine.

\section{Key to species of Rhinolekos}

1. Premaxillary and dentary accessory teeth present; caudal peduncle shallow (7.7-8.7\% of SL); $18-20$ (mode 19) middorsal plates........................................ Rhinolekos schaeferi

1 '. Premaxillary and dentary accessory teeth absent; caudalpeduncle deep (greater than $9.0 \%$ of SL); $21-27$ (mode 22 in $R$. britskii and 24 or 25 in $R$. garavelloi) mid-dorsal plates .2

2. Transverse dark band in pectoral, pelvic and anal-fin rays present; thoracic length $14.7-18.0 \%$ SL; 24-28 dorsal plates. .Rhinolekos britskii

2'. Transverse dark band in pectoral, pelvic and anal-fin rays absent; thoracic length 18.1-20.8\% SL; 30-35 dorsal plates. Rhinolekos garavelloi 


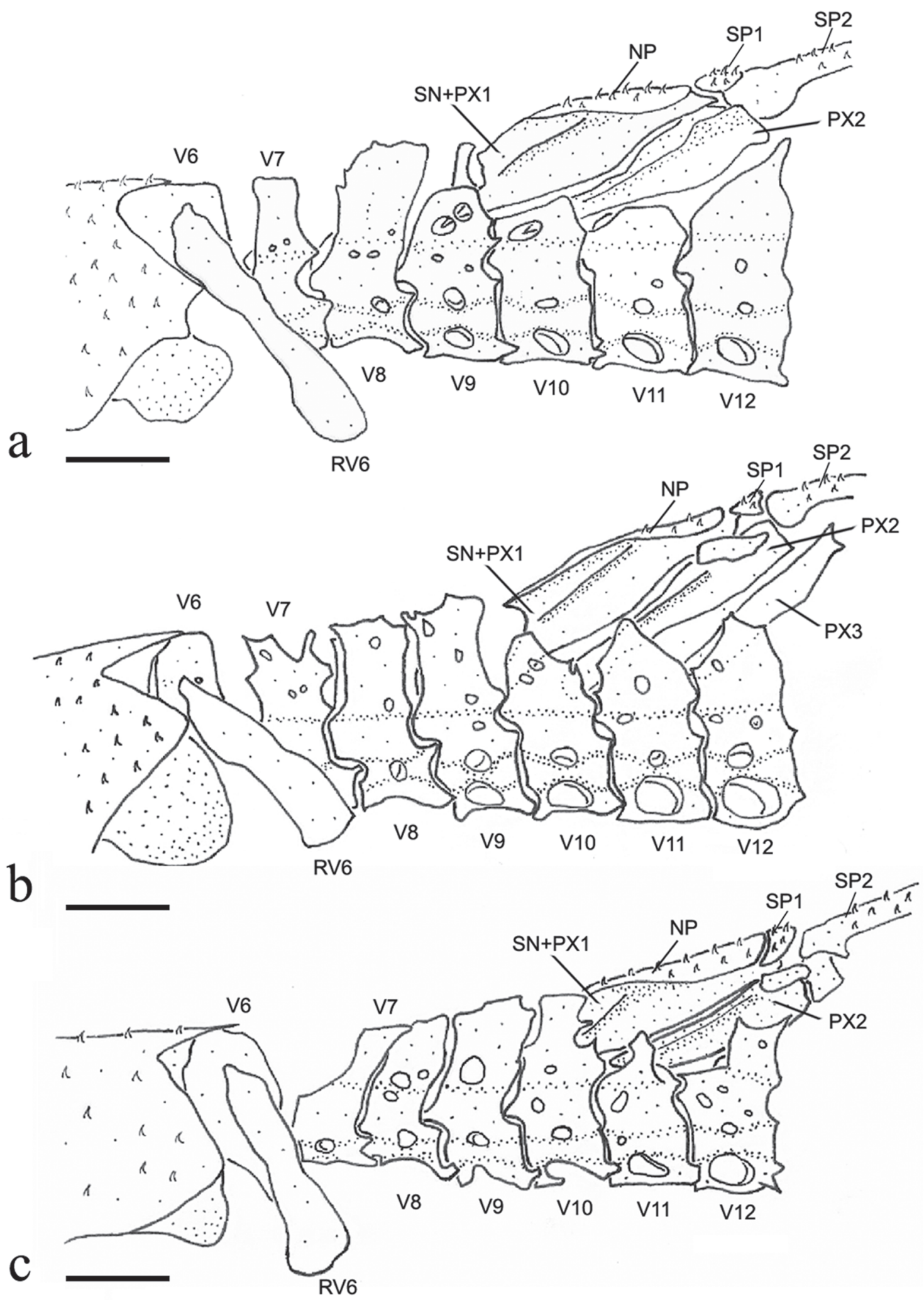

Fig. 1. Anterior portion of axial skeleton and dorsal-fin supports (left side, lateral view). a) Rhinolekos britskii, DZSJRP 6489, $28.0 \mathrm{~mm}$ SL. b) Rhinolekos garavelloi, DZSJRP 10477, $30.4 \mathrm{~mm}$ SL. c) Rhinolekos schaeferi, DZSJRP 12192, $36.5 \mathrm{~mm}$ SL. Scale bar $=1 \mathrm{~mm}$. Vertebrae counts included five from the Weberian apparatus. RV6 = rib of sixth vertebra; PX2-3 = compound proximal and medial radial 2-3; SN+PX1 = compound supraneural first dorsal-fin proximal radial; SP1 = first dorsal-fin spinelet; SP2 = second dorsal-fin spine; V6-12 = vertebrae 6-12. 


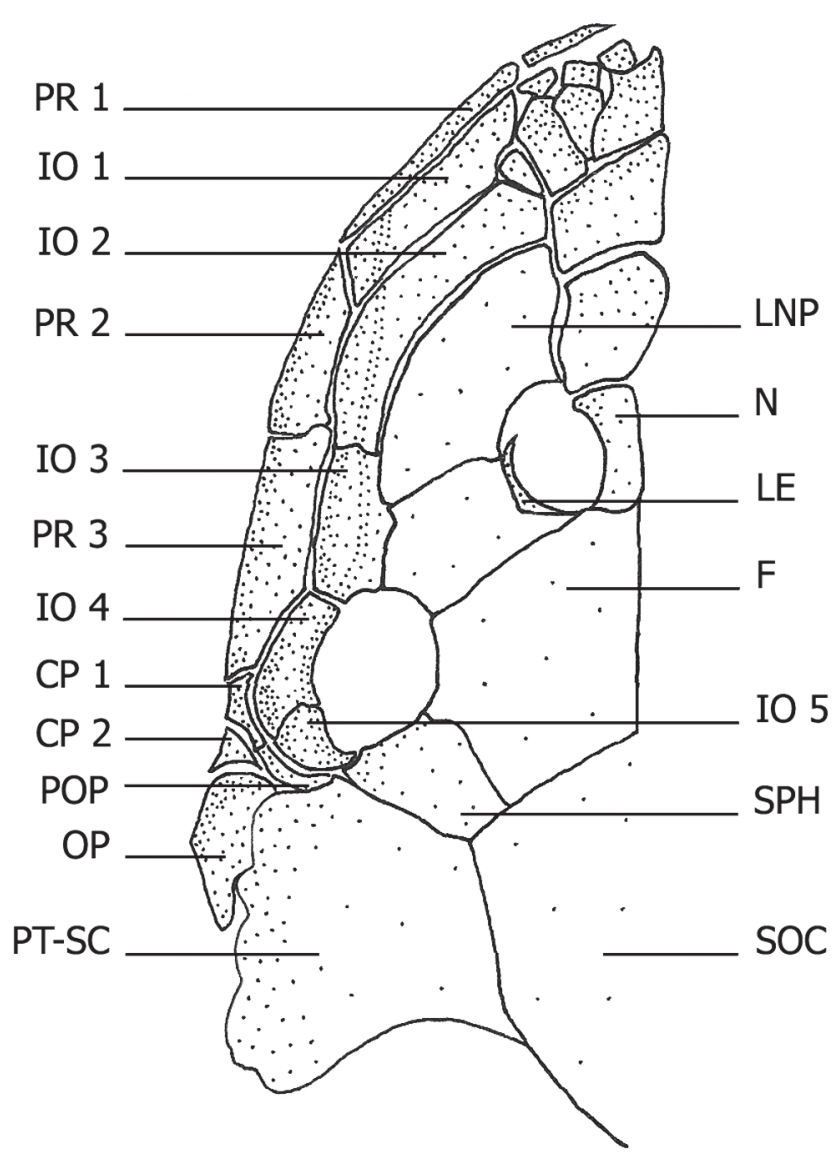

Fig. 2. Skull of Rhinolekos schaeferi (left side, dorsal view), paratype, DZSJRP 12192, $36.5 \mathrm{~mm}$ SL. Scale bar $=1 \mathrm{~mm}$. CP1$2=$ cheek plates $; \mathrm{F}=$ frontal; IO1-5 = infraorbitals $1-5 ; \mathrm{LE}=$ lateral ethmoid; $\mathrm{LNP}=$ lateronasal plate; $\mathrm{N}=$ nasal; $\mathrm{NP}=$ nuchal plate; $\mathrm{OP}=$ opercle; $\mathrm{PF}=$ prefontral plate; $\mathrm{POP}=$ preopercle; $\mathrm{PR} 1-3=$ postrostrals plates 1-3; $\mathrm{PT}-\mathrm{SC}=$ compound pterotic; $\mathrm{SOC}=$ supraoccipital; $\mathrm{SPH}=$ sphenotic.

\section{Rhinolekos britskii Martins, Langeani \& Costa, new species \\ Fig. 4}

Holotype. DZSJRP 6489, 32.2 mm SL, female, Brazil, Goiás State, Bela Vista de Goiás, tributary of the córrego Arapuca, Fazenda Arapuca, rio Paranaíba drainage, $17^{\circ} 04^{\prime} 06^{\prime \prime}$ S 48 43'59”'W, 29 Apr 2004, F. Langeani \& D. O. Tavares.

Paratypes. All from Brazil, Goiás State, rio Paranaíba drainage. DZSJRP 12190, 17, 1 c\&s, 21.8-35.5 mm SL (7, 31.9-35.5 mm SL), collected with holotype; DZSJRP 5567, 1, $19.7 \mathrm{~mm}$ SL, Bela Vista de Goiás, córrego Arapuca, dirt road of GO-020 (BR-352), $17^{\circ} 06^{\prime} 16^{\prime \prime S} 48^{\circ} 43^{\prime} 08^{\prime \prime}$ ', 22 May 2003, F. Langeani, J. P. Serra, F. R. Carvalho \& D. O. Tavares; DZSJRP 5604, 1, $18.4 \mathrm{~mm} \mathrm{SL}$, DZSJRP 5608, 1, $36.5 \mathrm{~mm}$ SL, Cristianópolis, córrego Gameleira,

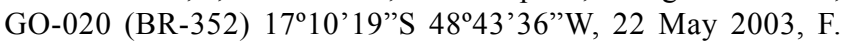
Langeani, J. P. Serra, F. R. Carvalho \& D. O. Tavares; DZSJRP

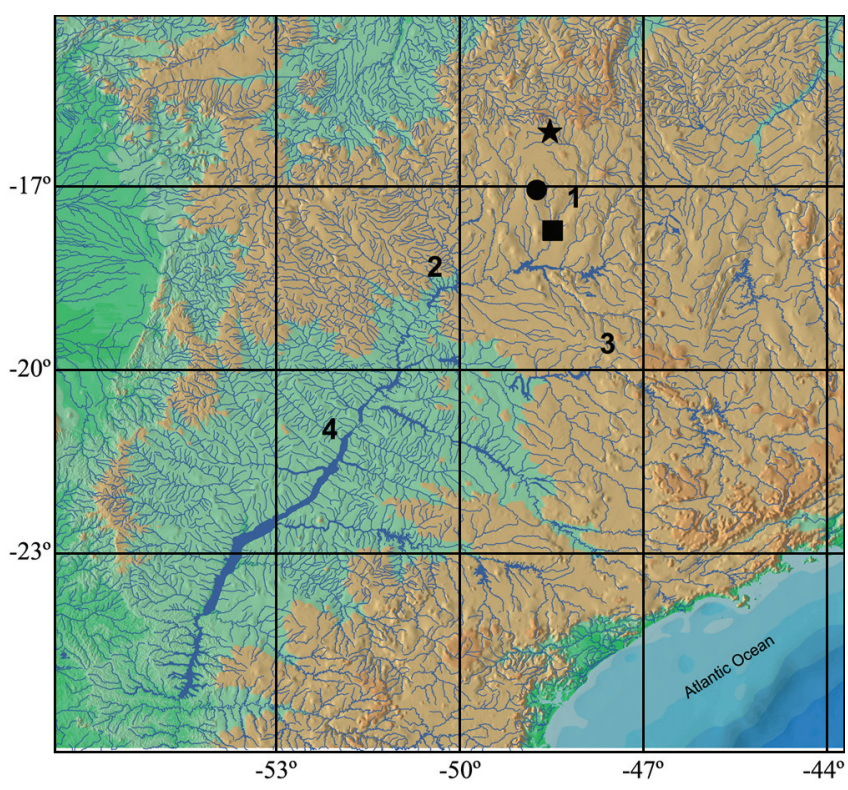

Fig. 3. Southeastern Brazil showing type locality of the Rhinolekos species (1 - rio Corumbá; 2 - rio Paranaíba; 3 - rio Grande; 4 - rio Paraná). Circle - R. britskii; Square - R. garavelloi; Star - R. schaeferi.

5614, 6, 14.3-34.4 mm SL (2, 33.6-34.4 mm SL), Bela Vista de Goiás, córrego Campo Alegre, 1709'09"S 4844'00"W, 22 May 2003, J. P. Serra, F. Langeani, F. R. Carvalho \& D. O. Tavares; DZSJRP 6514, 2, 23.7-35.6 mm SL (1, $35.6 \mathrm{~mm} \mathrm{SL})$, Bela Vista de Goiás, córrego dos Macacos, Fazenda Arapuca Velha, 1705'26”S 48 44'04'W, 29 Apr 2004, F. Langeani \& D. O. Tavares; DZSJRP 6884, 7, 2 c\&s, 22.2-38.2 mm SL (6, 30.7-38.2 mm SL). MZUSP 103698, 6, 26.7-36.3 mm SL (3, 30.7-36.3 mm SL), Bela Vista de Goiás, Corumbá tributary, Fazenda Arapuca, far away $25 \mathrm{~km}$ from GO-020, 1704'08'S, 4843'59”W, 25 Jul 2004, D. O. Tavares, G. A. Tavares \& D. J. Correa Jr.; DZSJRP 6983, 7, 1 c\&s, 16.8-40.0 mm SL, Bela Vista de Goiás, córrego dos Macacos, rio Corumbá, GO-020, Km 78, 1704'39'S 4843'20”W, 1 Nov 2004, D. O. Tavares, G. A. Tavares \& D. J. Correa Jr.; DZSJRP 7018, 12, 1 c\&s, 15.0-33.5 mm SL, (1, 33.5 mm SL), DZSJRP 7022, 1 c\&s, $31.2 \mathrm{~mm}$ SL, MCP 44058, 5, 22.2-36.0 mm SL (2, 32.4-36.0 mm SL), MNRJ 34128, 5, 26.1-35.5 mm SL (3, 31.1-35.5 mm SL), Bela Vista de Goiás, rio Corumbá tributary, GO-020, Km 78, 1704'08”S 48 44'01' W, 1 Nov 2004, D. O. Tavares, G. A. Tavares \& D. J. Correa Jr.; DZSJRP 7036, 2, 37.3-38.0 mm SL (1, $38.0 \mathrm{~mm} \mathrm{SL}$ ), Bela Vista de Goiás, córrego dos Macacos, rio Corumbá, GO-020, Km 78, 1704'38'S 4843'18'W, 6 Feb 2005, G. A Tavares, D. J. Correa Jr. \& W. C. Carmo; DZSJRP 7042, 6, 19.3-35.3 mm SL (1, $35.3 \mathrm{~mm} \mathrm{SL}$ ), Bela Vista de Goiás, rio Corumbá tributary, GO-020, Km 78, 1704'07'S 4843'59'W, 6 Feb 2005, G. A Tavares, D. J. Correa Jr. \& W. C. Carmo; DZSJRP 7045, 3, 34.6-37.5 mm SL, Bela Vista de Goiás, rio Corumbá tributary, GO-020, Km 78, 1705'27'’S 4844'40”'W, 6 Feb 2005, G. A. Tavares, D. J. Correa Jr. \& W. C. Carmo.

Diagnosis. Rhinolekos britskii differs from its congeners by the following characters: transverse dark bands in pectoral-, pelvic- and anal-fin rays present ( $v s$. absent); 31 vertebrae (vs.32), and by anterior portion of the compound supraneural- 


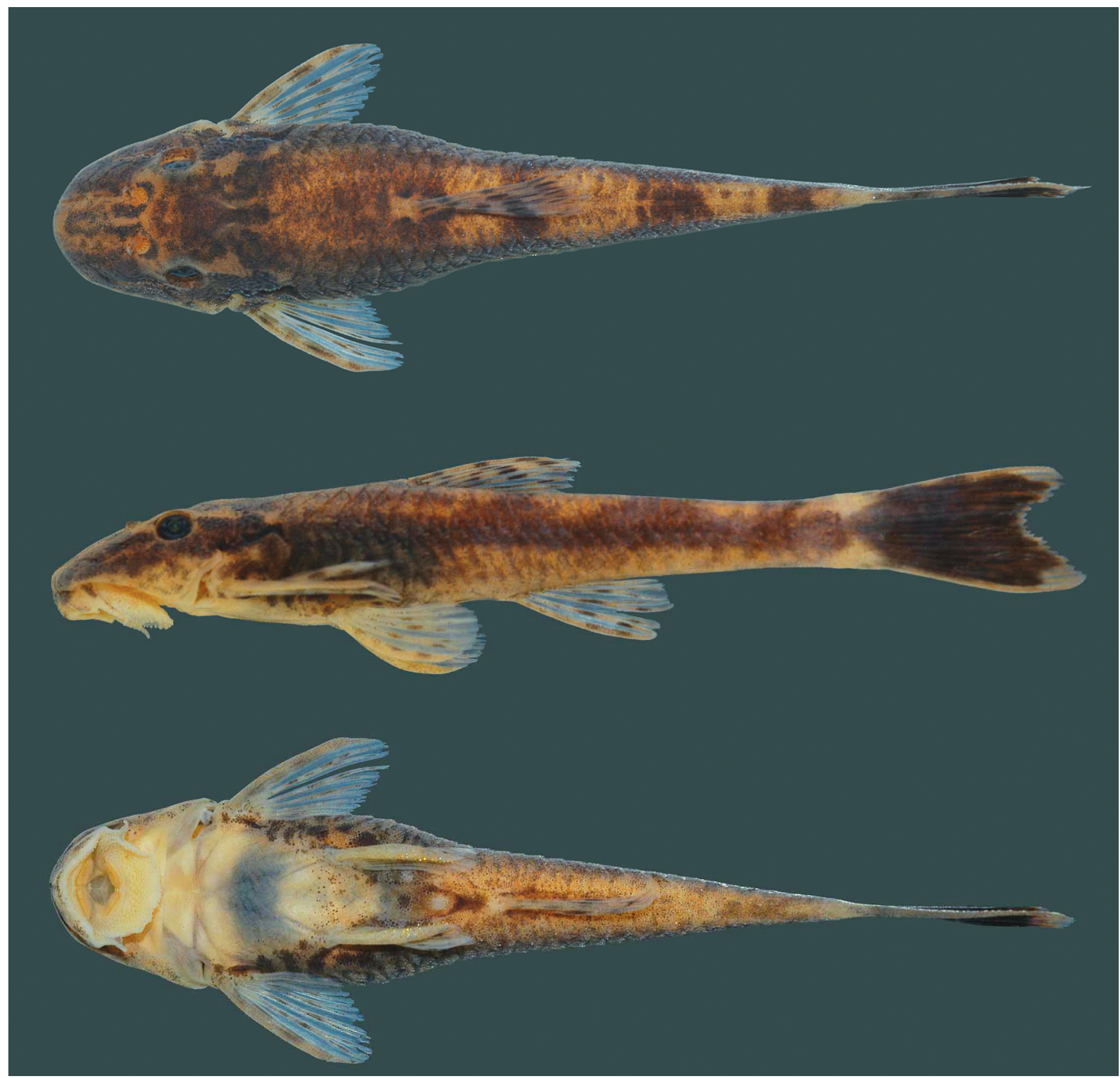

Fig. 4. Rhinolekos britskii, holotype, DZSJRP 6489, $32.2 \mathrm{~mm}$ SL, female, tributary of the córrego Arapuca, rio Paranaíba drainage, Bela Vista de Goiás, Goiás State, Brazil.

first dorsal-fin proximal radial contacting the neural spine of the $9^{\text {th }}$ vertebra $\left(v s .10^{\text {th }}\right)$. Furthermore, R. britskii could be distinguished from $R$. garavelloi by the larger postanal length (34.7-37.7\% in SL vs. 29.0-34.6\%); smaller thoracic length (14.7$18.0 \%$ in SL vs. 18.1-20.8\%); and fewer plates in the dorsal series (24-28 vs. 30-35). It differs from $R$. schaeferi by the absence of premaxillary and dentary accessory teeth ( $v s$. presence); and 21-24 mid-dorsal plates (vs. 18-20).

Description. Morphometric and meristic data are given in Tables 1 and 2. Dorsal body profile convex from tip of snout to dorsal-fin origin; concave at dorsal-fin base; almost straight to caudal-fin origin. Small elevation at supraoccipital immediately posterior to eyes. Ventral head profile slightly concave. Ventral body profile almost straight from pectoralfin origin to anal-fin origin, ascending at anal-fin base. Greatest body depth at dorsal-fin origin. Greatest body width at opercular region, gradually tapering towards snout and caudal fin. Head without longitudinal crests, anterior margin rounded in dorsal view. Snout without rostral plate, bearing numerous small plates with thin odontodes; most anterior portion of head naked. Odontodes equal in size and uniformly 
Table 1. Descriptive morphometrics of Rhinolekos britskii. Values given for holotype (H; DZSJRP 6489) and ranges of 30 specimens (DZSJRP 5614, 6514, 6884, 7018, 7036, 7042, 12190; MCP 44058; MNRJ 34128; MZUSP 103698); range includes holotype. $\mathrm{SD}=$ Standard deviation .

\begin{tabular}{|c|c|c|c|c|c|}
\hline & $\mathrm{H}$ & Minimum & Maximum & Mean & SD \\
\hline Standard length (mm) & 32.2 & 30.7 & 38.3 & - & - \\
\hline \multicolumn{6}{|c|}{ Percents of Standard length } \\
\hline Predorsal length & 46.8 & 44.1 & 48.9 & 46.7 & 1.3 \\
\hline Preanal length & 58.8 & 55.3 & 60.0 & 57.9 & 1.4 \\
\hline Prepectoral length & 25.4 & 22.4 & 26.4 & 25.1 & 0.9 \\
\hline Prepelvic length & 36.1 & 34.8 & 39.7 & 36.7 & 1.1 \\
\hline Postanal length & 35.2 & 34.7 & 37.7 & 36.0 & 1.0 \\
\hline Thoracic length & 17.1 & 14.7 & 18.0 & 16.9 & 1.0 \\
\hline Abdominal length & 21.6 & 19.5 & 23.9 & 21.3 & 1.0 \\
\hline Caudal-peduncle depth & 9.7 & 9.0 & 10.8 & 9.8 & 0.5 \\
\hline Head length & 29.2 & 27.6 & 32 & 30.2 & 1.0 \\
\hline Head w & 23.6 & 22.4 & 25.3 & 23.8 & 0.6 \\
\hline Head depth & 13.7 & 13.1 & 14.8 & 14.0 & 0.5 \\
\hline Base of dorsal-fin length & 11.4 & 9.8 & 13.3 & 11.9 & 0.9 \\
\hline Folded dorsal-fin length & 21.7 & 19.7 & 24.8 & 22.3 & 1.1 \\
\hline Pectoral-fin unbranched ray length & 21.7 & 16.2 & 23.2 & 20.8 & 1.4 \\
\hline Pelvic-fin unbranched ray length & 17.0 & 15.5 & 20.9 & 17.5 & 1.4 \\
\hline Snout-opercle length & 24.5 & 23.2 & 26.4 & 25.0 & 0.8 \\
\hline \multicolumn{6}{|c|}{ Percents of Head length } \\
\hline Head width & 78.8 & 73.1 & 82.4 & 78.7 & 2.5 \\
\hline Head depth & 45.9 & 42.8 & 49.3 & 46.5 & 1.8 \\
\hline Snout length & 54.6 & 51.6 & 57.3 & 54.4 & 1.4 \\
\hline Orbital diameter & 16.9 & 13.8 & 18.0 & 16.2 & 1.2 \\
\hline Interorbital length & 39.7 & 36.4 & 41.1 & 38.8 & 1.2 \\
\hline Barbel length & 6.2 & 3.5 & 9.2 & 6.1 & 1.1 \\
\hline Prenasal length & 37.3 & 32.3 & 39.8 & 36.9 & 1.8 \\
\hline Internasal length & 13.0 & 10.5 & 14.2 & 12.4 & 1.0 \\
\hline Suborbital depth & 24.2 & 21.9 & 29.3 & 25.0 & 1.6 \\
\hline
\end{tabular}

distributed, not forming rows, on head and body. Eye small, dorsolaterally placed, not visible from ventral view. Iris operculum present, very reduced in some specimens. Infraorbital canal entering infraorbital series via compound pterotic. Compound pterotic roughly quadrangular in shape, without elongate posterior extension, its posteroventral margin with irregular and median to large perforations. Supraoccipital not contributing to the dorsal portion of the swimbladder capsule.

Body entirely covered with bony plates, except on ventral part of head, region overlying opening of swim bladder capsule, and around anus and pelvic-fin origin. Abdomen covered with small plates irregularly arranged.

Lips roundish, papillose; lower lip larger than upper lip, with papillae gradually smaller towards edges. Maxillary barbel free from lower lip and reduced. Teeth slender, bifid; median cusp larger and rounded, lateral cusp smaller and pointed. Premaxillary teeth 19-28. Dentary teeth 18-25. Number of teeth increasing with size. Premaxillary and dentary accessory teeth absent.

Dorsal-fin rays ii,6-7, originating approximately at vertical through middle of pelvic fin; its length surpassing anal-fin origin; spinelet small, approximately rectangular, posterior margin slightly convex; locking mechanism non-functional.
Anterior portion of compound supraneural-first dorsal-fin proximal radial contacting neural spine of $9^{\text {th }}$ vertebra (Fig. 1a). Pectoral-fin rays i,6, originating immediately posterior to opercular opening and surpassing pelvic-fin origin. Cleithrum and coracoid exposed and supporting odontodes only laterally, near pectoral-fin insertion. Arrector fossae partially enclosed by ventral lamina of coracoid; opening relatively large, extending laterally halfway towards pectoralfin base. Pectoral-fin axillary slit present only in juvenile specimens. Pelvic-fin rays i,5, reaching anal-fin origin when depressed. Pectoral- and pelvic-fin unbranched ray shorter than branched rays; enlarged odontodes at tip of pectoralfin unbranched ray and at mesial margin of pelvic-fin unbranched ray. Anal-fin rays i,5. Caudal-fin rays i, 14,i, lower lobe slightly longer than upper lobe; four or five dorsal and four ventral procurrent rays. Adipose fin absent; replaced by single azygous plate in some specimens. Median lateral plates 26-30. Median-plate series complete, from compound pterotic to caudal-fin base, absence of canal in one plate near region of tenth median plate in some specimens. Vertebrae 31.

Color in alcohol. Ground color of dorsal surface brown. Trunk with four transverse dark bars: first at dorsal-fin origin, triangular in some specimens; second, ventral to dorsal-fin rays; third at vertical through middle of anal fin; last near caudal-fin insertion. Light brown area between tip of snout and nares. Opercle region unpigmented. Lateral portion of body brown, with dark longitudinal stripe, from compound pterotic to caudal-fin origin. Ventral surface of body mostly unpigmented. Dorsal-, anal-, pectoral-, and pelvic-fins membranes hyaline, with transverse dark bands along rays. Caudal fin densely pigmented, tip of lobes hyaline; some specimens, mainly juveniles, with a circular unpigmented area on each lobe. Procurrent rays sometimes with yellowish white coloration, extending laterally to caudal peduncle.

Sexual dimorphism. Males with conspicuous urogenital papillae immediately posterior to anus, and with a dorsal expanded flap of skin in all pelvic-fin rays.

Distribution. Streams from rio Paranaíba drainage, upper rio Paraná system, Goiás State, Brazil (Fig. 3).

Etymology. Named after Heraldo A. Britski, Museu de Zoologia da Universidade de São Paulo, in recognition of his dedication and remarkable contributions to the studies in Hypoptopomatinae and to Neotropical Ichthyology, in general.

Remarks. Filipi Cezaro Costa contributed to the description of Rhinolekos britskii and is therefore included as one of the authors of this species. 
Table 2. Frequency distribution of meristics for Rhinolekos britskii (DZSJRP 5614, 6514, 6884, 7018, 7022, 7036, 7042, 12190; MCP 44058; MNRJ 34128; MZUSP 103698).

\begin{tabular}{|c|c|c|c|}
\hline Character & Frequency distribution & Range & Mode \\
\hline Dorsal plates & & $24-28$ & 26 \\
\hline right side & $24(1) ; 25(1) ; 26(2) ; 27(1) ; 28(1)$ & & \\
\hline left side & $25(1) ; 26(3) ; 27(1) ; 28(1)$ & & \\
\hline Mid-dorsal plates & & $21-24$ & $21 / 22$ \\
\hline right side & $21(2) ; 22(2) ; 23(1) ; 24(1)$ & & \\
\hline left side & $21(2) ; 22(2) ; 23(1) ; 24(1)$ & & \\
\hline Median plates & & $26-30$ & 27 \\
\hline right side & $26(1) ; 27(2) ; 28(2) ; 30(1)$ & & \\
\hline left side & $26(1) ; 27(3) ; 28(2)$ & & \\
\hline Mid-ventral plates & & $22-25$ & 22 \\
\hline right side & $22(2) ; 23(3) ; 25(1)$ & & \\
\hline left side & $22(4) ; 23(1) ; 25(1)$ & & \\
\hline Ventral plates & & $24-29$ & $26 / 27 / 28$ \\
\hline rigth side & $26(1) ; 27(1) ; 28(3) ; 29(1)$ & & \\
\hline left side & $24(1) ; 26(2) ; 27(2) ; 29(1)$ & & \\
\hline Premaxillary teeth & & $19-28$ & 25 \\
\hline right side & $20(1) ; 22(1) ; 23(2) ; 25(1) ; 28(1)$ & & \\
\hline left side & 19(1);21(1);22(1);24(1);25(2) & & \\
\hline Dentary teeth & & $18-25$ & 20 \\
\hline right side & $18(1) ; 19(1) ; 20(2) ; 23(1) ; 24(1)$ & & \\
\hline left side & $18(1) ; 19(1) ; 20(1) ; 21(1) ; 24(1) ; 25(1)$ & & \\
\hline Dorsal-fin branched rays & $6(4) ; 7(26)$ & $6-7$ & 7 \\
\hline Pectoral-fin branched rays & $6(30)$ & - & 30 \\
\hline Pelvic-fin branched rays & $5(30)$ & - & 5 \\
\hline Anal-fin branched rays & $5(30)$ & - & 5 \\
\hline Caudal-fin branched rays & $14(30)$ & - & 14 \\
\hline Dorsal procurrent rays & $4(2) ; 5(2)$ & $4-5$ & - \\
\hline Ventral procurrent rays & $4(4)$ & 4 & 4 \\
\hline Vertebrae & $31(4)$ & - & 31 \\
\hline
\end{tabular}

\section{Rhinolekos garavelloi Martins \& Langeani, new species \\ Fig. 5}

Holotype. DZSJRP 10479, 31.4 mm SL, male, Brazil, Goiás State, Caldas Novas, rio Paranaíba drainage, stream at Fazenda Lageado, near GO-213 road, after rio Corumbá bridge, 1744'20"S 482'27’'W, 8 Jun 2007, F. Langeani, L. G. G. Silveira, D. Simiele, M. M. F. Marinho \& J. P. Serra.

Paratypes. All from same locality of holotype. DZSJRP 10477, $22,3 \mathrm{c} \& \mathrm{~s}, 15.2-36.2 \mathrm{~mm}$ SL (11, 31.2-36.2 mm SL), MCP 44057, 6, 24.8-32.2 mm SL (3, 30.6-32.2 mm SL), 11 May 2007, L. G. G. Silveira \& F. Langeani. DZSJRP 12191, 37, 4 c\&s, 10.7-32.8 mm SL (11, 29.8-32.8 mm SL), MNRJ 34127, 5, 21.4-32.5 mm SL (2, 29.0-32.5 mm SL), MZUSP 103697, 5, 20.0-31.3 mm SL (2, 31.2$31.3 \mathrm{~mm} \mathrm{SL}$ ), collected with the holotype.

Diagnosis. Rhinolekos garavelloi differs from its congeners by the following characters: shorter postanal length (29.0$34.6 \%$ in SL $v$ s. $34.7-37.7 \%$ in $R$. britskii and $35.7-41.3 \%$ in $R$. schaeferi); longer thoracic length (18.1-20.8\% in SL vs. 14.7$18.0 \%$ in R. britskii and $13.7-17.6 \%$ in R. schaeferi); $30-35$ dorsal plates (vs. 24-28 in R. britskii and 26-28 in R. schaeferi). Furthermore, it could be distinguished from $R$. britskii by the absence of transverse dark bands in pectoral-, pelvicand anal-fin rays ( $v s$. presence); by having 32 vertebrae ( $v s$. 31 ), and anterior portion of the compound supraneural-first dorsal-fin proximal radial contacting the neural spine of the $10^{\text {th }}$ vertebra $\left(v s .9^{\text {th }}\right)$. It further differs from $R$. schaeferi by having 23-27 mid-dorsal plates (vs. 18-20); 24-28 mid-ventral plates (vs. 20-22); higher caudal peduncle (10.3-13.0\% in SL vs. 7.7-8.7); wider head (24.6-28.1\% in SL vs. 20.5-23.9\%); premaxillary and dentary accessory teeth absent ( $v s$. present).

Description. Morphometric and meristic data are given in Tables 3 and 4. Dorsal body profile convex from tip of snout to dorsal-fin origin; concave at dorsal-fin base; straight to caudal-fin origin. Small elevation at supraoccipital immediately posterior to eyes. Ventral head profile slightly concave. Ventral body profile almost straight from pectoral-fin origin to analfin origin, ascending at anal-fin base. Greatest body depth at dorsal-fin origin. Greatest body width at opercular region, gradually tapering toward snout and caudal-fin. Head without longitudinal crests, anterior margin rounded in dorsal view. Snout without rostral plate, bearing numerous small plates with thin odontodes; most anterior portion of head naked. Odontodes equal in size and uniformly distributed, not forming rows, on head and body. Eye small; dorsolaterally placed, not visible in ventral view. Iris operculum present. Infraorbital canal entering infraorbital series via compound pterotic. Compound pterotic roughly quadrangular in shape, without elongate posterior extension, its posteroventral margin with irregular and median to large perforations. Supraoccipital not contributing to the dorsal portion of the swimbladder capsule.

Body entirely covered with bony plates, except on ventral 

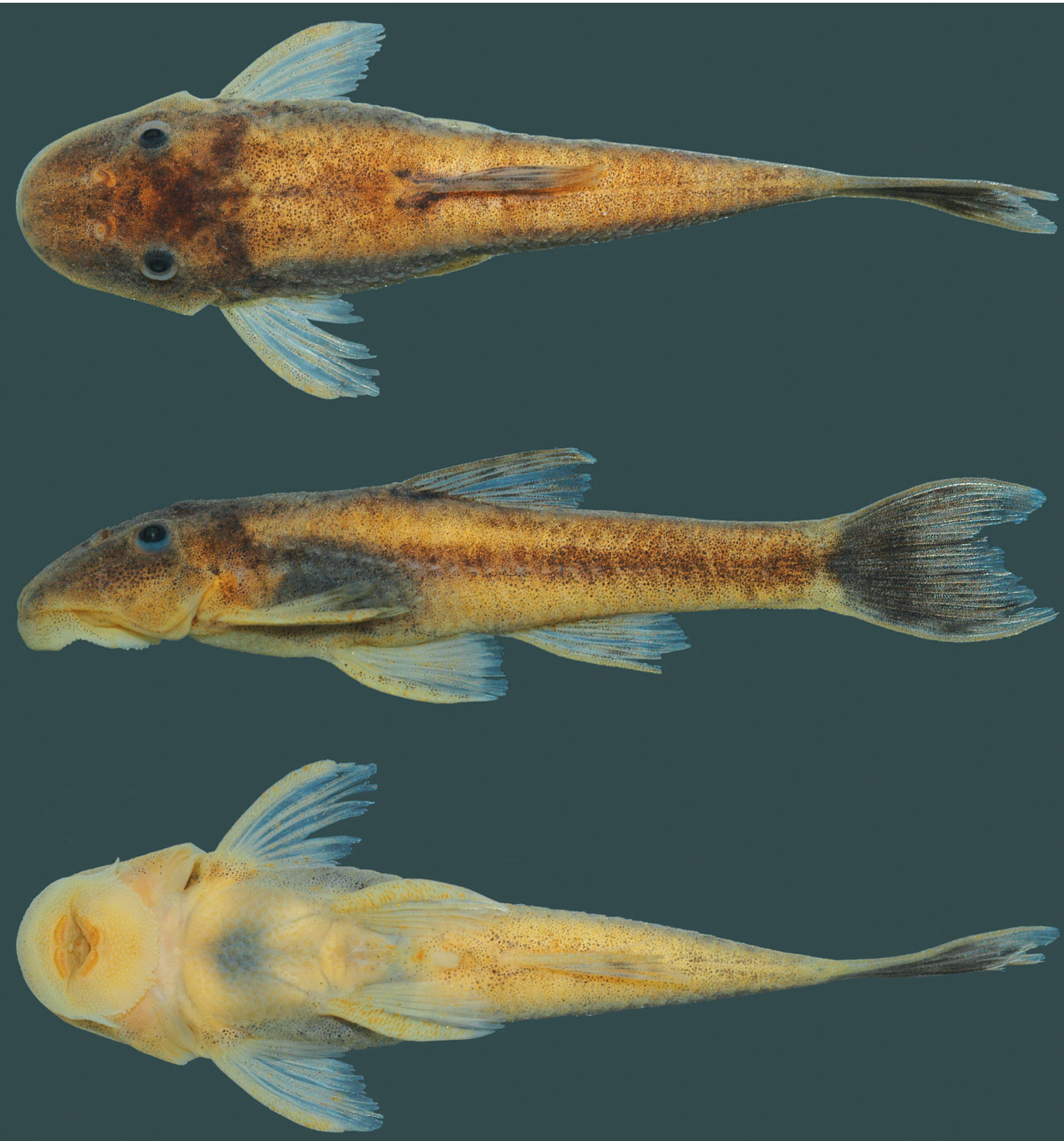

Fig. 5. Rhinolekos garavelloi, holotype, DZSJRP 10479, 31.4 mm SL, male, stream at Fazenda Lageado, rio Paranaíba drainage, Caldas Novas, Goiás State, Brazil.

part of head, region overlying opening of swim bladder capsule and around anus and pelvic-fin origin. Abdomen covered with small plates irregularly arranged.

Lips roundish, papillose; lower lip larger than upper lip, with papillae gradually smaller towards edges. Maxillary barbel free from lower lip and reduced. Teeth slender, bifid; median cusp larger and rounded, lateral cusp smaller and pointed. Premaxillary teeth 20-34. Dentary teeth 18-31. Number of teeth increasing with size of specimen. Premaxillary and dentary accessory teeth absent.

Dorsal-fin rays ii,6-7; originating at vertical through middle of pelvic fin; its length surpassing anal-fin origin; spinelet small, roughly triangular shaped; locking mechanism non-functional. Anterior portion of compound supraneuralfirst dorsal-fin proximal radial contacting neural spine of $10^{\text {th }}$ vertebra (Fig. 1b). Pectoral-fin rays i, 6 , originating immediately posterior to opercular opening, surpassing pelvic-fin origin. Cleithrum and coracoid exposed and supporting odontodes only laterally, near pectoral-fin insertion. Arrector fossae partially enclosed by ventral lamina of coracoid; opening relatively large, extending laterally halfway towards pectoral-fin base. Pectoral-fin axillary slit present only in juvenile specimens. Pelvic-fin rays i,4-5, reaching anal-fin origin when depressed. Pectoral- and 
Table 3. Descriptive morphometrics of Rhinolekos garavelloi. Values given for holotype (H; DZSJRP 10479) and range of 30 specimens (DZSJRP 10477, 12191; MCP 44057; MNRJ 34127; MZUSP 103697); range includes holotype. $\mathrm{SD}=$ Standard deviation.

\begin{tabular}{|c|c|c|c|c|c|}
\hline & $\mathrm{H}$ & Minimum & Maximum & Mean & $\mathrm{SD}$ \\
\hline Standard length (mm) & 31.4 & 29.0 & 36.2 & - & - \\
\hline \multicolumn{6}{|c|}{ Percents of Standard length } \\
\hline Predorsal length & 50.4 & 46.6 & 53.3 & 49.1 & 1.5 \\
\hline Preanal length & 62.0 & 57.8 & 66.0 & 60.5 & 1.8 \\
\hline Prepectoral length & 27.9 & 24.4 & 29.7 & 27.0 & 1.2 \\
\hline Prepelvic length & 38.3 & 36.0 & 42.3 & 38.5 & 1.2 \\
\hline Postanal length & 30.9 & 29.0 & 34.6 & 31.8 & 1.3 \\
\hline Thoracic length & 20.3 & 18.1 & 20.8 & 19.5 & 0.8 \\
\hline Abdominal length & 22.3 & 20.6 & 25.7 & 23.2 & 1.2 \\
\hline Caudal-peduncle depth & 11.9 & 10.3 & 13.0 & 11.5 & 0.5 \\
\hline Head length & 34.0 & 29.3 & 35.3 & 32.6 & 1.2 \\
\hline Head width & 26.6 & 24.6 & 28.1 & 26.0 & 0.8 \\
\hline Head depth & 16.1 & 13.2 & 16.2 & 15.1 & 0.6 \\
\hline Base of dorsal-fin length & 10.1 & 9.3 & 12.6 & 11.0 & 0.9 \\
\hline Folded dorsal-fin length & 23.4 & 22.4 & 25.7 & 23.5 & 0.8 \\
\hline Pectoral-fin unbranched ray length & 20.1 & 16.6 & 21.1 & 19.4 & 1.1 \\
\hline Pelvic-fin unbranched ray length & 20.2 & 15.2 & 21.1 & 18.7 & 1.6 \\
\hline Snout-opercle length & 28.1 & 24.7 & 28.5 & 26.7 & 0.8 \\
\hline \multicolumn{6}{|c|}{ Percents of Head length } \\
\hline Head width & 78.3 & 69.9 & 87.1 & 79.7 & 3.2 \\
\hline Head depth & 47.2 & 40.6 & 52.3 & 46.2 & 2.3 \\
\hline Snout length & 51.3 & 48.5 & 59.6 & 52.9 & 2.6 \\
\hline Orbital diameter & 14.3 & 12.9 & 16.8 & 15.1 & 1.0 \\
\hline Interorbital length & 36.4 & 34.7 & 42.1 & 37.3 & 1.4 \\
\hline Barbel length & 8.6 & 6.5 & 9.9 & 8.2 & 0.7 \\
\hline Prenasal length & 32.6 & 32.5 & 42.2 & 35.5 & 2.1 \\
\hline Internasal length & 9.5 & 9.5 & 14.4 & 11.5 & 1.0 \\
\hline Suborbital depth & 26.7 & 22.3 & 28.1 & 25.7 & 1.5 \\
\hline
\end{tabular}

pelvic-fin unbranched rays smaller than branched rays; enlarged odontodes at tip of pectoral-fin unbranched ray and at mesial margin of pelvic-fin unbranched ray. Anal-fin rays i,3-5. Caudal-fin rays i,14-15,i; lower lobe slightly longer than upper lobe, in some specimens; four or five dorsal and 3-6 ventral procurrent rays. Adipose fin and azygous plates absent. Median lateral plates 28-32. Median-plate series complete, from compound pterotic to caudal-fin base, absence of canal in one or two plates near region of tenth median plate in some specimens. Vertebrae 32.

Color in alcohol. Ground color of dorsal surface light brown; posterior portion of head with transverse dark bar. Trunk with four conspicuous bars: first at dorsal-fin origin; second at end of dorsal-fin base; third at vertical through middle anal fin; last at caudal-fin insertion; less conspicuous in adult specimens. Head darker than remaining portion of dorsum. Clear area between tip of snout and nares. Opercle region unpigmented. Lateral portion of body light brown with dark longitudinal stripe, from compound pterotic to caudal-fin origin. Ventral surface of body mostly unpigmented. Dorsal, anal-, pectoral- and pelvic-fins membranes hyaline. Dorsal-fin rays with higher concentration of chromatophores, forming transverse bands. Caudal fin homogeneously dark; tip of lobes unpigmented. Procurrent rays with yellowish white coloration sometimes, extending laterally to caudal peduncle.

Table 4. Frequency distribution of meristics for Rhinolekos garavelloi (DZSJRP 10477, 12191; MCP 44057; MNRJ 34127; MZUSP 103697).

\begin{tabular}{|c|c|c|c|}
\hline Character & Frequency distribution & Range & Mode \\
\hline Dorsal plates & & $30-35$ & 34 \\
\hline right side & $30(2) ; 31(1) ; 32(1) ; 34(2) ; 35(1)$ & & \\
\hline left side & $31(2) ; 32(2) ; 33(1) ; 34(2)$ & & \\
\hline Mid-dorsal plates & & $23-27$ & $24 / 25$ \\
\hline right side & $24(2) ; 25(3) ; 26(2)$ & & \\
\hline left side & $23(1) ; 24(2) ; 25(1) ; 27(3)$ & & \\
\hline Median plates & & $28-32$ & $30 / 31$ \\
\hline right side & 29(2); 30(1); 31(2); 32(2) & & \\
\hline left side & 28(1); 29(1); 30(3); 31(2) & & \\
\hline Mid-ventral plates & & $24-28$ & 24 \\
\hline right side & $24(2) ; 25(4) ; 28(1)$ & & \\
\hline left side & $24(4) ; 25(1) ; 27(2)$ & & \\
\hline Ventral plates & & $27-33$ & 27 \\
\hline right side & $27(1) ; 28(2) ; 30(2) ; 33(1)$ & & \\
\hline left side & $27(3) ; 28(1) ; 29(1) ; 32(1)$ & & \\
\hline Premaxillary teeth & & $20-34$ & 20 \\
\hline right side & $20(1) ; 24(2) ; 32(1) ; 33(1) ; 34(2)$ & & \\
\hline left side & $20(2) ; 22(1) ; 30(1) ; 31(1) ; 32(1) ; 33(1)$ & & \\
\hline Dentary teeth & & $18-31$ & $18 / 28 / 29$ \\
\hline right side & $18(3) ; 27(1) ; 28(1) ; 29(1) ; 31(1)$ & & \\
\hline left side & $19(1) ; 20(2) ; 28(2) ; 29(2)$ & & \\
\hline Dorsal-fin branched rays & $6(9) ; 7(27)$ & $6-7$ & 7 \\
\hline Pectoral-fin branched rays & $6(36)$ & - & - \\
\hline Pelvic-fin branched rays & $4(1) ; 5(35)$ & $4-5$ & 5 \\
\hline Anal-fin branched rays & $3(1) ; 4(1) ; 5(34)$ & $3-5$ & 5 \\
\hline Caudal-fin branched rays & $14(33) ; 15(3)$ & $14-15$ & 14 \\
\hline Dorsal procurrent rays & $4(5) ; 5(1)$ & $4-5$ & 4 \\
\hline Ventral procurrent rays & $3(1) ; 4(2) ; 5(2) ; 6(1)$ & $3-6$ & $4 / 5$ \\
\hline Vertebrae & $32(5)$ & - & 32 \\
\hline
\end{tabular}




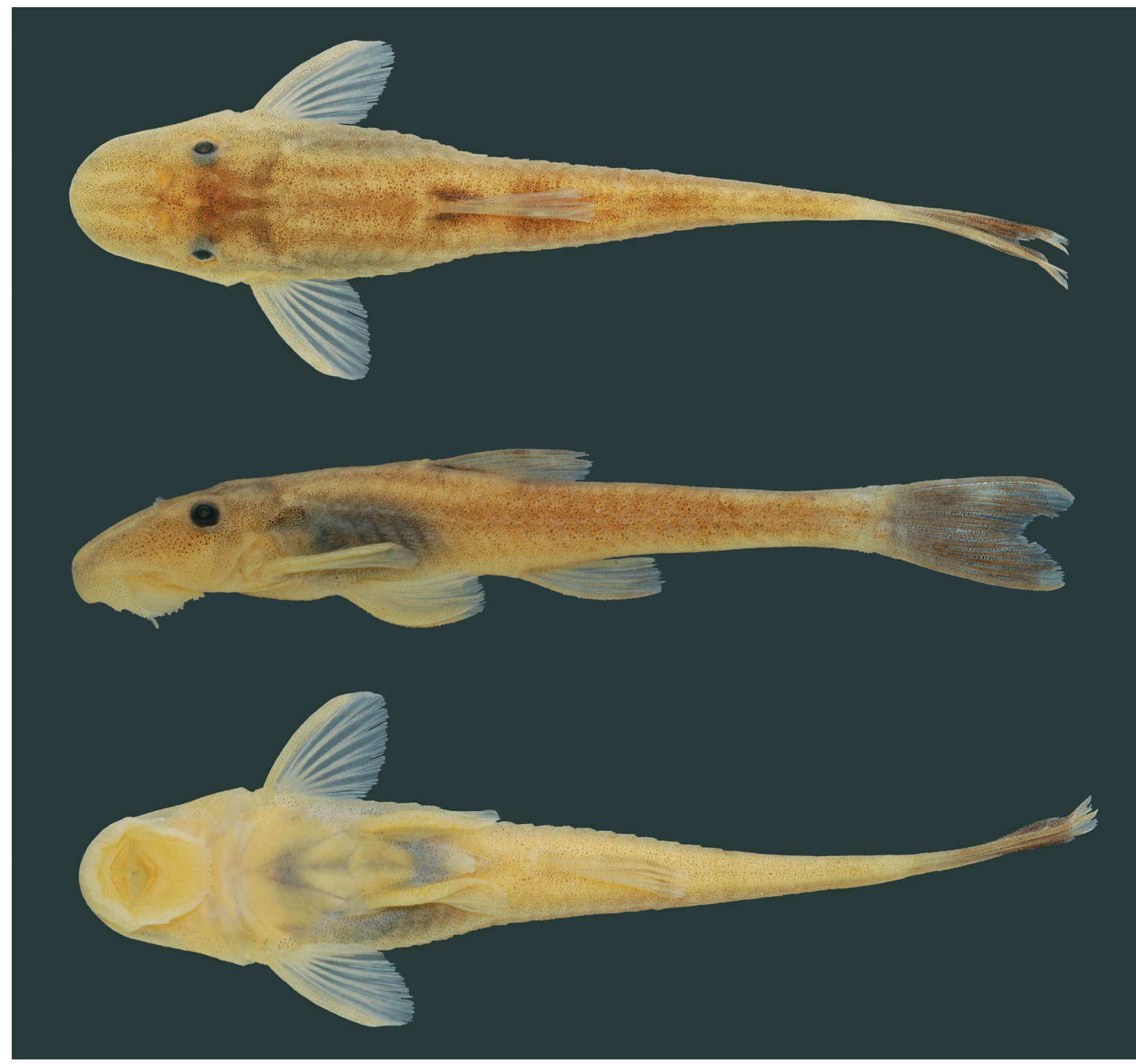

Fig. 6. Rhinolekos schaeferi, holotype, MCP 26939, 35.4 mm SL, male, córrego Fazenda at Chácara Fernanda, rio Paranaíba drainage, Alexânia, Goiás State, Brazil.

Sexual dimorphism. Males with conspicuous urogenital papillae immediately posterior to anus and first pelvic-fin ray with a dorsal expanded flap of skin.

Distribution. Known from the type locality, stream tributary to rio Paranaíba drainage, upper rio Paraná system, Caldas Novas, Goiás State, Brazil (Fig. 3).

Etymology. Named after Julio C. Garavello, Universidade Federal de São Carlos, for his contributions to the study of Hypoptopomatinae catfishes and to Neotropical Ichthyology.

\section{Rhinolekos schaeferi Martins \& Langeani, new species} Fig. 6

Holotype. MCP 26939, 35.4 mm SL, male, Brazil, Goiás State, Alexânia, rio Paranaíba drainage, córrego Fazenda at Chácara Fernanda, $c a .16^{\circ} 07^{\prime} \mathrm{S} 48^{\circ} 31^{\prime} \mathrm{W}, 31$ Dec 2000, R. E. Reis.

Paratypes. All collected with holotype. DZSJRP 12192, 3 , 1 c\&s, 36.5-38.4 mm SL (2, 37.0-38.4 mm SL). MCP 44056, 12, 2 c\&s, 27.2-37.3 mm SL (10, 27.2-37.3 mm SL).

Diagnosis. Rhinolekos schaeferi differs from its congeners by the following characters: premaxillary and dentary 
accessory teeth present ( $v s$. absent); shallower caudal peduncle (7.7-8.7\% in SL vs. 9.0-10.8\% in R. britskii and 10.2$13.0 \%$ in R. garavelloi); $18-20$ mid-dorsal plates (vs. $21-24$ in R. britskii and 23-27 in R. garavelloi). Furthermore, it differs from $R$. britskii by having transverse dark bands in pectoral, pelvic- and anal-fin rays absent, (vs. present) 32 vertebrae (vs. 31), and anterior portion of the compound supraneuralfirst dorsal-fin proximal radial contacting the neural spine of the $10^{\text {th }}$ vertebra ( $\left.v s .9^{\text {th }}\right)$. It is further distinguished from $R$. garavelloi by having 26-28 dorsal plates (vs. 30-35); 20-22 mid-ventral plates (vs. 24-28); larger postanal length (35.7$41.3 \%$ in SL vs. 29.0-34.6\%); shorter thoracic length (13.7$17.6 \%$ in SL vs. 18.1-20.8\%); and slender head, width 20.5$22.9 \%$ in SL (vs. 24.6-28.1\%).

Description. Morphometric and meristic data are given in Tables 5 and 6. Dorsal body profile convex from tip of snout to dorsal-fin origin; concave at dorsal-fin base; almost straight to caudal-fin origin. Small elevation at supraoccipital immediately posterior to eyes. Ventral head profile slightly concave. Ventral body profile almost straight from pectoral-fin origin to anal-fin origin, ascending at anal-fin base. Greatest body depth at dorsalfin origin. Greatest body width at opercular region, gradually tapering toward snout and caudal fin. Head without longitudinal crests, anterior margin rounded in dorsal view. Snout without rostral plate, bearing numerous small plates with thin odontodes; most anterior portion of head naked. Odontodes equal in size and uniformly distributed, not forming rows, on head and body. Eye small; dorsolaterally placed, not visible in ventral view. Iris operculum present. Infraorbital canal entering infraorbital series via compound pterotic. Compound pterotic roughly quadrangular in shape, without elongate posterior extension, its posteroventral margin with irregular and median to large perforations. Supraoccipital not contributing to the dorsal portion of the swimbladder capsule.

Body entirely covered with bony plates, except on ventral part of head, region overlying opening of swim bladder capsule, and around anus and pelvic-fin origin. Abdomen covered with small plates irregularly arranged.

Lips roundish, papillose; lower lip larger than upper lip, with papillae gradually smaller towards edges. Maxillary barbel free from lower lip and reduced. Teeth slender, bifid; median cusp larger and rounded, lateral cusp smaller and pointed. Premaxillary teeth 27-30. Dentary teeth 24-30. Number of teeth increasing with size of specimen. Premaxillary and dentary accessory teeth present.

Dorsal-fin rays ii,6-7; originating approximately at vertical through urogenital opening; its length surpassing vertical through middle of anal fin; spinelet small, approximately rectangular, with posterior margin slightly convex; locking mechanism non-functional. Anterior portion of compound supraneural-first dorsal-fin proximal radial contacting neural spine of $10^{\text {th }}$ vertebra (Fig. 1c). Pectoral-fin rays i,6; originating immediately posterior to opercular opening; surpassing pelvicfin origin. Cleithrum and coracoid exposed and supporting odontodes only laterally, near pectoral-fin insertion. Arrector fossae partially enclosed by ventral lamina of coracoid; opening relatively large, extending laterally halfway towards pectoralfin base. Pectoral-fin axillary slit present only in juvenile specimens. Pelvic-fin rays i,5, not reaching anal-fin origin when depressed. Pectoral- and pelvic-fin unbranched rays smaller than branched rays; enlarged odontodes at tip of pectoral-fin unbranched ray and at mesial margin of pelvic-fin unbranched ray. Anal-fin rays i,5. Caudal-fin rays i,14,i; lobes equal in size; three or four dorsal and three or four ventral procurrent rays. Adipose fin and azygous plates absent. Median lateral plates 26-29. Median-plate series complete, from compound pterotic to caudal-fin base. Vertebrae 32 .

Color in alcohol. Ground color of dorsal surface light brown. Trunk with four transverse inconspicuous bars: first at dorsalfin origin; second, ventral to dorsal-fin rays; third at vertical through end of anal fin; last near caudal-fin insertion. Clear area between tip of snout and nares. Opercle region unpigmented. Lateral portion of body light brown with inconspicuous longitudinal stripe, from compound pterotic to caudal-fin origin. Ventral surface of body mostly unpigmented. Dorsal-, anal-, pectoral- and pelvic-fins membranes hyaline; dorsal- and anal-fin rays with dense concentration of chromatophores over rays. Caudal fin uniformly dark; tip of lobes unpigmented; some specimens, mainly juveniles, with a circular unpigmented area on each lobe. Procurrent rays sometimes with yellowish white coloration, extending laterally to caudal peduncle.

Sexual dimorphism. Males with conspicuous urogenital papillae immediately posterior to anus, and with a dorsal expanded flap of skin in all pelvic-fin rays.

Distribution. Known from type locality, a stream tributary to rio Paranaíba drainage, upper rio Paraná system, Alexânia, Goiás State, Brazil (Fig. 3).

Etymology. Named after Scott A. Schaefer, American Museum of Natural History, for his remarkable contributions for the Hypoptopomatinae systematics.

Remarks. All examined specimens of $R$. schaeferi present iris operculum extremely reduced, almost inconspicuous. Since the iris operculum may vary according to level of illumination (Douglas et al., 2002), this reduction is probably a result of the light intensity at the moment these specimens were collected.

\section{Discussion}

In all Hypoptopomatinae species, except for Acestridium, Gymnotocinclus, and Rhinolekos, the second infraorbital is a large plate surrounding the nasal opening. This is also the 
Table 5. Descriptive morphometrics of Rhinolekos schaeferi. Values given for holotype (H; MCP 26939) and ranges of 13 specimens (DZSJRP 12192; MCP 44056); range includes holotype. $\mathrm{SD}=$ Standard deviation.

\begin{tabular}{|c|c|c|c|c|c|}
\hline & $\mathrm{H}$ & Minimum & Maximum & Mean & $\mathrm{SD}$ \\
\hline Standard length (mm) & 35.4 & 27.2 & 38.5 & - & - \\
\hline \multicolumn{6}{|c|}{ Percents of Standard length } \\
\hline Predorsal length & 47.7 & 45.5 & 50.1 & 47.8 & 1.5 \\
\hline Preanal length & 56.5 & 55.2 & 58.5 & 56.5 & 1.1 \\
\hline Prepectoral length & 26.0 & 23.7 & 27.5 & 25.6 & 1.0 \\
\hline Prepelvic length & 34.4 & 34.3 & 36.6 & 35.3 & 0.7 \\
\hline Postanal length & 38.3 & 35.7 & 41.3 & 37.9 & 1.6 \\
\hline Thoracic length & 13.9 & 13.7 & 17.6 & 15.3 & 1.2 \\
\hline Abdominal length & 22.1 & 19.8 & 22.2 & 20.9 & 0.9 \\
\hline Caudal-peduncle depth & 8.6 & 7.7 & 8.7 & 8.2 & 0.3 \\
\hline Head length & 30.0 & 29.0 & 32.2 & 30.7 & 1.1 \\
\hline Head width & 20.8 & 20.5 & 22.9 & 21.6 & 0.9 \\
\hline Head depth & 13.0 & 11.8 & 14.8 & 13.2 & 0.8 \\
\hline Base of dorsal-fin length & 11.1 & 9.4 & 12.5 & 11.2 & 0.7 \\
\hline Folded dorsal-fin length & 19.5 & 18.9 & 23.4 & 20.5 & 1.2 \\
\hline Pectoral-fin unbranched ray length & 18.5 & 16.1 & 20.5 & 18.2 & 1.1 \\
\hline Pelvic-fin unbranched ray length & 17.0 & 14.0 & 19.6 & 16.2 & 1.3 \\
\hline Snout-opercle length & 25.1 & 23.9 & 26.2 & 25.1 & 0.8 \\
\hline \multicolumn{6}{|c|}{ Percents of Head length } \\
\hline Head width & 69.3 & 65.3 & 75.3 & 70.5 & 3.0 \\
\hline Head depth & 43.3 & 39.4 & 46.3 & 43.0 & 2.3 \\
\hline Snout length & 58.4 & 53.3 & 59.4 & 56.3 & 1.6 \\
\hline Orbital diameter & 14.2 & 12.6 & 17.3 & 14.7 & 1.2 \\
\hline Interorbital length & 39.2 & 32.3 & 40.0 & 35.9 & 2.0 \\
\hline Barbel length & 5.8 & 3.7 & 6.6 & 5.2 & 0.8 \\
\hline Prenasal length & 40.7 & 37.6 & 41.3 & 39.3 & 1.1 \\
\hline Internasal length & 8.5 & 8.2 & 11.2 & 9.5 & 1.0 \\
\hline Suborbital depth & 22.5 & 21.9 & 27.4 & 23.8 & 1.8 \\
\hline
\end{tabular}

condition in all other Loricariidae examined. Acestridium, Gymnotocinclus, and Rhinolekos, however, have a large plate between the second infraorbital and the nasal opening, the lateronasal plate, which does not bear the infraorbital canal. In juvenile specimens of Rhinolekos, the lateronasal plate is small and positioned at the posterior edge of the nares. During development, the lateronasal plate projects anteriorly, dislodging the second infraorbital to a more ventral position, and limiting the nasal opening laterally. The presence of this plate in Acestridium, is probably an independent acquisition, due to the phylogenetic position occupied by the genus, inserted among other Hypoptopomatini. In the other hand, the presence of the lateronasal plate in Gymnotocinclus anosteos and Rhinolekos species is also probably not homologous, because Gymnotocinclus is probably the basalmost genus in the subfamily based on the presence of: nasal capsule entirely closed by the lateral ethmoid ventrally (vs. nasal organ partially open from bellow in Rhinolekos and remaining Hypoptopomatinae taxa, except Acestridium); metapterygoid channel shallow, its depth much less than $50 \%$ of its length (vs. metapterygoid channel deep, its depth about $50 \%$ of its length in Rhinolekos and most other Hypoptopomatinae, except the Hypoptopomatini); preopercle ventral margin not reflected medially ( $v s$. preopercle ventral margin reflected medially in Rhinolekos and most other Hypoptopomatinae, except the Hypoptopomatini); fourth infraorbital not expanded ventrally ( $v s$. fourth infraorbital expanded ventrally in
Table 6. Frequency distribution of meristics for Rhinolekos schaeferi (DZSJRP 12192; MCP 44056)

\begin{tabular}{|c|c|c|c|}
\hline Character & Frequency distribution & Range & Mode \\
\hline $\begin{array}{l}\text { Dorsal plates } \\
\text { right side } \\
\text { left side }\end{array}$ & $\begin{array}{c}26(1) ; 27(1) ; 28(1) \\
26(2) ; 28(2)\end{array}$ & $26-28$ & 26 \\
\hline $\begin{array}{l}\text { Mid-dorsal plates } \\
\text { right side } \\
\text { left side }\end{array}$ & $\begin{array}{c}18(1) ; 19(1) ; 20(1) \\
18(1) ; 19(2)\end{array}$ & $18-20$ & 19 \\
\hline $\begin{array}{l}\text { Median plates } \\
\text { right side } \\
\text { left side }\end{array}$ & $\begin{array}{l}26(1) ; 27(1) ; 28(1) \\
26(1) ; 27(1) ; 29(1)\end{array}$ & $26-29$ & $26 / 27$ \\
\hline $\begin{array}{l}\text { Mid-ventral plates } \\
\text { right side } \\
\text { left side }\end{array}$ & $\begin{array}{l}20(1) ; 22(2) \\
20(1) ; 22(2)\end{array}$ & $20-22$ & 22 \\
\hline $\begin{array}{l}\text { Ventral plates } \\
\text { right side } \\
\text { left side }\end{array}$ & $\begin{array}{c}22(1) ; 23(1) ; 27(1) \\
23(2) ; 25(1)\end{array}$ & $22-27$ & 23 \\
\hline $\begin{array}{l}\text { Premaxillary teeth } \\
\text { right side } \\
\text { left side }\end{array}$ & $\begin{array}{c}19(1) ; 28(2) \\
21(1) ; 27(1), 30(1)\end{array}$ & $19-30$ & 28 \\
\hline $\begin{array}{l}\text { Dentary teeth } \\
\text { right side } \\
\text { left side }\end{array}$ & $\begin{array}{l}17(1) ; 24(1) ; 28(1) ; \\
16(1) ; 25(1) ; 30(1)\end{array}$ & $16-30$ & - \\
\hline Dorsal-fin branched rays & $6(1) ; 7(12)$ & $6-7$ & 7 \\
\hline Pectoral-fin branched rays & $6(13)$ & 6 & 6 \\
\hline Pelvic-fin branched rays & $5(13)$ & 5 & 5 \\
\hline Anal-fin branched rays & $5(13)$ & 5 & 5 \\
\hline Caudal-fin branched rays & $14(13)$ & 14 & 14 \\
\hline Dorsal procurrent rays & $3(1) ; 4(2)$ & $3-4$ & 4 \\
\hline Ventral procurrent rays & $3(1) ; 4(1)$ & $3-4$ & 4 \\
\hline Vertebrae & $32(2)$ & - & 32 \\
\hline
\end{tabular}

Rhinolekos and most other Hypoptopomatinae, except the Hypoptopomatini); anterior portion of the compound supraneural-first dorsal-fin proximal radial contacting the neural spine of the $7^{\text {th }}$ vertebra ( $v s$. anterior portion of the compound supraneural-first dorsal-fin proximal radial contacting the neural spine of the $9^{\text {th }}$ or $10^{\text {th }}$ vertebrae in Rhinolekos). Furthermore, as already stated by Carvalho et al. (2008), the presence of an adnate maxillary barbel in Gymnotocinclus seems to be an additional plesiomorphic feature ( $v s$. free maxillary barbel in Rhinolekos and most other Hypoptopomatinae).

According to Schaefer (1998), the loricariids generally have the compound supraneural-first dorsal-fin proximal radial ( $\mathrm{SN}+\mathrm{PX} 1)$ supported by the seventh vertebra and contacting the anterodorsal portion of the eighth vertebra. Among the hypoptopomatines, Epactionotus, and Parotocinclus jumbo Britski \& Garavello 2002 (Bárbara Calegari pers. commun.), present the $\mathrm{SN}+\mathrm{PX} 1$ supported by the eighth vertebra; Microlepidogaster also has the derived condition with the $\mathrm{SN}+\mathrm{PX} 1$ supported by the eighth (our observation) or ninth vertebrae in M.perforata and by the tenth or eleventh vertebra in $M$. longicolla Calegari \& Reis, 2010. In R. britskii the contact of the SN+PX1 occurs on the ninth vertebra, $R$. garavelloi and $R$. schaeferi present the anterior portion of the $\mathrm{SN}+\mathrm{PX} 1$ contacting the neural spine of the tenth vertebra (Fig. 1). We think that the dorsal fin insertion modified many times among the Hypoptopomatinae, being independently acquired in the genera cited above. 
According to Reis \& Schaefer (1998), many species of the Hypoptopomatinae have a slit-like opening near pectoral-fin insertion, the pectoral-fin axillary slit. They also indicated the presence of a pectoral-fin axillary slit in other members of the order Siluriformes, such as Cetopsidae, Pseudopimelodidae, Pimelodidae, and an undescribed Neoplecostomus species. During our observations, we also identified the pectoral-fin axillary slit in other additional siluriform families: such as Aspredinidae, Auchenipteridae, Callichthyidae, Doradidae, Heptapteridae, and Trichomycteridae. Scoloplacidae was the single family analyzed that lacks the pectoral slit. Furthermore, within the Loricariidae, the pectoral slit is also present in the subfamilies Loricariinae, Hypostominae, and Neoplecostominae. Apparently only the Ancistrinae lacks this features (specimens of the Delturinae were not examined until now). Consequently, the presence of the pectoral-fin axillary slit seems to be a synapomorphy much more inclusive than previously thought.

We observed that the pectoral-fin axillary slit is absent in large specimens of other loricariids, occuring only in juveniles, as in the majority of the Neoplecostominae and some Hypoptopomatinae, such as Pseudotocinclus, Microlepidogaster longicolla, all Rhinolekos species (our observation) and Hisonotus megaloplax (Carvalho \& Reis, 2009). The presence of the pectoral-fin axillary slit only in juveniles, up to $20.0 \mathrm{~mm}$ of SL, is another diagnostic character for the genus Rhinolekos. Otothyris travassossi and Schizolecis guntheri are the only hypoptopomatines analyzed until now in which the pectoral slit is always absent, even in the juvenile specimens. The character remains to be confirmed in Gymnotocinclus anosteos, for which the adults do not have the pectoral-fin axillary slit and no juvenile specimens were analyzed. Among all examined taxa, we also found a variation in the shape and position of the pectoral slit, which together with the developmental variation may be used as character states in future phylogenetic analysis.

Comparative material. Acestridium discus: MZUSP 7126, $1 \mathrm{c \& s,}$ igarapé Tarumanzinho, Manaus, Amazonas. Ancistrus sp.: DZSJRP 11966, 38, 1 c\&s, córrego Seco, Bonito, Mato Grosso do Sul. Auchenipterus osteomystax: DZSJRP 10991, rio Uruguay drainage, Dom Pedrito, Rio Grande do Sul. Bunocephalus rugosus: DZSJRP 5763, 1, rio Paraguai drainage, Mirassol D'Oeste, Mato Grosso. Cetopsis gobioides: DZSJRP 12390, 2, rio Tietê drainage, Ipeúna, São Paulo. Corumbataia tocantinensis: MZUEL 4998, 22, 1 c\&s, rio das Almas drainage, Rianápolis, Goiás. Corydoras aeneus: DZSJRP 9947, 19, rio Dourado, Quarantã, São Paulo. Epactionotus bilineatus: DZSJRP 11358, 4, 1 c\&s, rio Maquiné, Maquiné, Rio Grande do Sul. Euricheilichthys pantherinus: DZSJRP 11429, 6, 2 c\&s, rio Silveira, São José dos Ausentes, Rio Grande do Sul. Gymnotocinclus anosteos: MCP 41726, paratypes, 5, 1 c\&s, rio Tocantizinho tributary, rio Tocantins drainage, Alto Paraíso de Goiás, Goiás. Hassar wilderi: DZSJRP 7881, 1, rio Araguaia, Barra do Garças, Mato Grosso. Hisonotus leucofrenatus: MZUSP 68199, 3; MZUSP 69401, 2, both from rio Faú, Miracatu, São Paulo. Hypoptopoma inexspectatum: DZSJRP 1559, 1, rio Miranda, Miranda, Mato Grosso do Sul. Hypostomus ancistroides: DZSJRP
6268, 2, rio Borá, Nova Aliança, São Paulo. Kronichthys sp.: DZSJRP 6526, 4, 1 c\&s, stream at Jardim São Lourenço, Bertioga, São Paulo. Lampiella gibbosa: MZUSP 70640, 26, ribeirão Palmeiras, rio Catas Altas, Ribeira, São Paulo. Loricaria similima: DZSJRP 2024, 1, rio Paraná drainage, Bataiporã, Mato Grosso do Sul. Microglanis sp.: DZSJRP 8667, 7, rio Paranaíba drainage, Araguari, Minas Gerais. Microlepidogaster perforata: MNRJ 31886, 13, 2 c\&s, rio Carandaí, Carandaí, Minas Gerais. Microlepidogaster sp.: DZSJRP 8750, 25, 2 c\&s, riacho Grotão, Uberaba, Minas Gerais. Nannoptopoma sp.: MZUSP 36219, 11, rio Solimões, Coari, Amazonas. Neoplecostomus microps: DZSJRP 2144, 23, 1 c\&s, riacho Jardim do Paraíso, Cunha, São Paulo; DZSJRP 4269, 5, rio Piquete, Piquete, São Paulo. Otocinclus vitattus: MZUSP 54161, 29, rio Paraguay drainage, Alto Paraguay. Otothyris travassossi: MZUSP 51442, 9, rio Mucuri, Mucuri, Bahia. Otothyropsis marapoama: DZSJRP 9937,12, 1 c\&s, ribeirão Três Pontes, Novo Horizonte, São Paulo; LIRP 5641, paratypes, 48, 3 c\&s, córrego Cubatão, Tietê drainage, Catanduva, São Paulo. Oxyropsis aff. wrightiana: MZUSP 36228, 1, rio Negro tributary, São Gabriel da Cachoeira, Amazonas. Parotocinclus cf. cearensis: UFPB 4107, 23, rio Paraíba do Norte, Itabaiana, Paraíba. Parotocinclus cesarpintoi: MNRJ 1154, 62, rio Paraíba, Quebrângulo, Alagoas. Parotocinclus doceanus: MZUSP 1016, 1, rio Doce, Espírito Santo. Paratype of Parotocinclus haroldoi: MNRJ 10532, 1, córrego do Otaviano, Piauí. Parotocinclus jumbo: MZUSP 69519, paratype, 1 c\&s, rio Paraíba do Norte, Congo, Paraíba. Parotocinclus maculicauda: MZUSP 8680, 28, 1 c\&s, Prata-Mendanha tributary, Rio de Janeiro. Phenacorhamdia tenebrosa: DZSJRP 10509, 3, rio Paranaíba dranaige, Ipameri, Goiás. Pseudotocinclus tietensis: DZSJRP 6940, 2, 1 c\&s, rio Paraitinga, Salesópolis, São Paulo; LBP 2964, 3, 1 c\&s, rio Paraitinga, Salesópolis, São Paulo. Pseudotothyris obtusa: DZSJRP 3152, 6, 1 c\&s, rio Ribeira do Iguape drainage, Jacupiranga, São Paulo. Rhinelepis aspera: DZSJRP 4495, 1, rio Paranapanema drainage, São Paulo. Schizolecis guntheri: DZSJRP 2299, 6, 1 c\&s, rio Ribeira do Iguape drainage, Jacupiranga, São Paulo. Scoloplax sp.: DZSJRP 9196, 10, Tocantins-Araguaia drainage, Cocalinho, Mato Grosso. Sorubim lima: DZSJRP 3180, 2, rio Paraguay drainage, Miranda, Mato Grosso do Sul. Trichomycterus brasiliensis: DZSJRP 8623, 38, upper rio Paraná drainage, Carmo de Minas, Minas Gerais.

\section{Acknowledgements}

We thank Heraldo A. Britski (MZUSP), Roberto E. Reis (MCP), Pablo Lehmann (UNISINOS), and two anonymous reviewers for suggestions which largely improved this manuscript; José Lima de Figueiredo (MZUSP) for providing access to specimens deposited at MZUSP; Heraldo A. Britski (MZUSP), Paulo A. Buckup (MNRJ), Claudio Oliveira (LBP), and Roberto E. Reis (MCP) for the loan of specimens; Jane P. Serra (DZSJRP) for the help with photographs; Bárbara B. Calegari (MCP) for the counts on some specimens deposited in MCP; Diego O. Tavares for some samplings, and Manoela M. F. Marinho for providing some specimen data and suggestions. Filipi Cezaro Costa contributed to discovery and description of $R$. britskii. This study was supported by Fundação de Amparo à Pesquisa do Estado de São Paulo (FAPESP 2004/00545-8, FL; FAPESP 2005/02449-9, FCC; 2008/ 00597-9, FOM) and Conselho Nacional de Desenvolvimento Científico e Tecnológico (CNPq 306.988/2008-9, FL). 


\section{Literature Cited}

Armbruster, J. W. \& L. M. Page. 1996. Redescription of Aphanotorulus (Teleostei: Loricariidae) with description of one new species, $A$. ammophilus, from the Rio Orinoco basin. Copeia, 1996(2): 379-389.

Bailey, R. M. \& J. N. Baskin. 1976. Scoloplax dicra, a new armored catfishe from the Bolivian Amazon. Occasional Papers of the Museum of Zoology University of Michigan, 674: 1-14.

Boeseman, M. 1968. The genus Hypostomus Lacépède 1803, and Surinam representatives (Siluriformes: Loricariidae). Zoologische Verhandelingen, 99: 1-89.

Britski, H. A. \& J. C. Garavello. 2002. Parotocinclus jumbo, a new species of the subfamily Hypoptopomatinae from northeastern Brazil (Ostariophysi: Loricariidae). Ichthyological Exploration of Freshwaters, 13(3): 279-288.

Calegari, B. B. \& R. E. Reis. 2010. Anew species of Microlepidogaster (Siluriformes: Loricariidae: Hypoptopomatinae) from the upper rio Paraná basin, Brazil. Neotropical Ichthyology, 8(3): 625-630.

Carvalho, T. P., P. Lehmann \& R. E. Reis. 2008. Gymnotocinclus anosteos, a new uniquely-plated genus and species of loricariid catfish (Teleostei: Siluriformes) from the upper rio Tocantins basin, central Brazil. Neotropical Ichthyology, 6(3): 329-338.

Carvalho, T. P. \& R. E. Reis. 2009. Four new species of Hisonotus (Siluriformes: Loricariidae) from tem upper rio Uruguay, southeastern South America, with a review of the genus in the rio Uruguay basin. Zootaxa, 2113: 1-40.

Douglas, R. H., S. P. Collin \& J. Corrigan. 2002. The eyes of suckermouth armoured catfish (Loricariidae, subfamily Hypostomus): pupil response, lenticular longitudinal spherical aberration and retinal topography. The Journal of Experimental Biology, 205: 3425-3433.

Fricke, R. \& W. N. Eschmeyer. 2010. A guide to fish collections in the Catalog of Fishes database. http://research.calacademy.org/ redirect?url=http://researcharchive.calacademy.org/research/ Ichthyology/catalog/collections.asp. Accessed January 28, 2010.
Reis, R. E. \& T. P. Carvalho. 2007. Hypoptopomatinae. Pp. 82-87. In: Buckup, P. A., N. A. Menezes \& M. S. Ghazzi (Eds.). Catálogo das Espécies de Peixes de Água Doce do Brasil. Museu Nacional, Rio de Janeiro, 195p.

Reis, R. E. \& S. A. Schaefer. 1998. New Cascudinhos from Southern Brazil: Systematics, Endemism, and Relationships (Siluriformes, Loricariidae, Hypoptopomatinae. American Museum Novitates, 3254: 1-25.

Ribeiro, A. R., M. Carvalho \& A. L. A. Melo. 2005. Description and relationship of Otothyropsis marapoama, a new genus and species of Hypoptopomatinae catfish (Siluriformes: Loricariidae) from rio Tietê basin, southeastern Brazil. Neotropical Ichthyology, 3(4): 489-498.

Schaefer, S. A. 1997. The Neotropical cascudinhos: Systematics and biogeography of the Otocinclus catfishes (Siluriformes: Loricariidae). Proceedings of the Academy of Natural Sciences of Philadelphia, 148: 1-120.

Schaefer, S. A. 1998. Conflict and resolution: impact of new taxa on phylogenetic studies of the neotropical cascudinhos (Siluroidei: Loricariidae). Pp. 375-400. In: Malabarba, L. R., R. E. Reis, R. P. Vari, Z. M. S. Lucena \& C. A. S. Lucena (Eds.). Phylogeny and Classification of Neotropical Fishes. Porto Alegre, Edipucrs, $603 \mathrm{p}$.

Schaefer, S. A. 2003. Subfamily Hypoptomatinae (Armored catfishes). Pp. 321-329. In: Reis, R. E., S. O. Kullander \& C. J. Ferraris, Jr. (Eds.). Check List of the Freshwater Fishes of South and Central America. Porto Alegre, Edipucrs, 729p.

Schaefer, S. A. \& F. Provenzano. 1993. The Guyana Shield Parotocinclus: systematics, biogeography, and description of a new Venezuelan species (Siluroidei: Loricariidae). Ichthyological Exploration of Freshwaters, 4(1): 39-56.

Taylor, W. R. \& G. C. van Dyke. 1985. Revised procedures for staining and clearing small fishes and other vertebrates for bone and cartilage study. Cybium, 9(2): 107-119.

Accepted October 21, 2010 Published March 31, 2011 